\title{
NITROGEN DYNAMICS IN SOIL MANAGEMENT SYSTEMS. II - MINERALIZATION AND NITRIFICATION RATES ${ }^{(1)}$
}

\author{
Eduardo Garcia Cardoso ${ }^{(2)}$, João Carlos de Moraes Sá ${ }^{(3)}$, Clever Briedis ${ }^{(2)}$, \\ Ademir de Oliveira Ferreira ${ }^{(4)}$, Paulo Rogério Borszowskei ${ }^{(5)}$, Josiane Burkner \\ Santos $^{(6)}$, Aline Massinham ${ }^{(7)}$, Carla Fernanda Ferreira ${ }^{(7)}$, Darci Siuta \\ Júnior $^{(7)}$ \& Edemar José Baranek ${ }^{(7)}$
}

\begin{abstract}
SUMMARY
Nitrogen is the main limiting factor in crop productivity and thereby soil management systems may change the mineralization and nitrification rates. In an experiment on soil management systems implemented in 1988 at the experimental station Fundação ABC, Ponta Grossa, in the central South region of the State of Paraná, inorganic $\mathrm{N}$ dynamics were examined to find a soil management strategy with a view to a sustainable environment. The objective of this study was to calculate the net mineralization and nitrification rates of soil $\mathrm{N}$ and the correlation with soil pH under management systems. Randomized complete block design was used, in split plots, in three replications. The following soil management systems (SMSs) were adopted in the plots: 1) conventional tillage (CT); 2) minimum tillage (MT); 3) no-tillage with chisel plow every three years $\left(\mathrm{NT}_{\mathrm{CH}}\right)$; and 4 ) continuous no-tillage (CNT). To evaluate the dynamics of inorganic N, samples were collected from subplots at different times (11 sampling times - $\mathrm{T}_{1}$ to $\left.\mathrm{T}_{11}\right)$. In the $\mathrm{CNT}$ and $\mathrm{NT}_{\mathrm{CH}}$, the net mineralization rates were higher in the MT and CT systems in the 0-2.5 cm soil layer, while the nitrification rate was higher in the $2.5-5 \mathrm{~cm}$ layer. Soon after implementing the white oat management, the mineralization and nitrification rates in all soil layers were higher in the MT and CT systems. In the period of soybean
\end{abstract}

\footnotetext{
(1) Part of a master's thesis, presented by the first author to the Postgraduate Program in Agronomy at the Universidade Estadual de Ponta Grossa - UEPG. Received for publication in January 13, 2011 and approved in August $11,2011$.

(2) Master's degree in Agronomy from the Universidade Estadual de Ponta Grossa - UEPG. CEP 84030-900 Ponta Grossa (PR). E-mails: edugcardoso@yahoo.com.br; cleverbriedis@yahoo.com.br

(3) Professor in the Department of Soils at the UEPG. E-mail: jcmsa@uepg.br

(4) Doctorate in Soil Science from the Universidade Federal de Santa Maria. Santa Maria (RS). E-mail: aoferreira1@yahoo.com.br

(5) Master's degree in Agronomy from the UEPG. E-mail: paulobrave2@yahoo.com.br

(6) Doctorate in Agronomy from the Universidade Federal do Paraná. Curitiba (PR). E-mail: agroburk@yahoo.com.br

(7) Agronomic Engineering degree from the UEPG. E-mails: alinemassinham@yahoo.com.br; cferferreira@yahoo.com.br; siutajr@yahoo.com.br; edemarjb@yahoo.com.br
} 
development, in the $0-2.5$ and $2.5-5 \mathrm{~cm}$ soil layers, the mineralization and nitrification rates were higher in the $\mathrm{CNT}$ and $\mathrm{NT}_{\mathrm{CH}}$ than in the MT and CT systems.

Index terms: conservation systems, no-tillage, conventional tillage, soil pH.

\title{
RESUMO: DINÂMICA DO NITROGÊNIO EM SISTEMAS DE MANEJO DO SOLO. II - TAXAS DE MINERALIZAÇÃO E NITRIFICAÇÃO
}

\begin{abstract}
O nitrogênio é o principal fator limitante na produtividade das culturas e sistemas de manejo do solo podem alterar as taxas de mineralização e de nitrificação. Em experimento sobre sistemas de manejo do solo implantado em 1988, na Estação Experimental da Fundação $A B C$, de Ponta Grossa, região Centro-Sul do Estado do Paraná, foi realizado um estudo sobre a dinâmica do nitrogênio inorgânico, visando contribuir para a estratégia de manejo dos solos que conduzam à sustentabilidade ambiental. O objetivo deste trabalho foi calcular as taxas líquidas de mineralização e nitrificação do $\mathrm{N}$ no solo e a correlação com o pH do solo, afetados por sistemas de manejo. O delineamento experimental utilizado foi o de blocos completos ao acaso, em esquema de parcelas subdivididas com três repetições. As parcelas foram constituídas pelos seguintes SMS: 1) preparo convencional (PC); 2) preparo mínimo (PM); 3) plantio direto com escarificação a cada três anos (PDE); e 4) plantio direto permanente (PDP). Para avaliar a dinâmica do $N$ inorgânico, as subparcelas foram constituídas pelo tempo de coleta (11 tempos de coleta $-T_{1}$ a $T_{11}$ ). Nos sistemas PDP e PDE, as taxas líquidas de mineralização foram superiores às de PMe PC, na camada de 0-2,5 cm do solo, enquanto na camada de 2,5$5 \mathrm{~cm}$ a taxa de nitrificação foi maior. Logo após o manejo da aveia branca, as taxas de mineralização e nitrificação, em todas as camadas do solo, foram maiores no PMe no PC. No período de desenvolvimento da cultura da soja, nas camadas de 0-2,5 e 2,5-5 cm do solo as taxas de mineralização e nitrificação foram superiores nos sistemas PDP e PDE.
\end{abstract}

Termos de indexação: sistemas conservacionistas, plantio direto, cultivo convencional, $p H$ do solo.

\section{INTRODUCTION}

Nitrogen is one of the main limiting factor of crop productivity, and many studies have sought possibilities to reduce the need for $\mathrm{N}$ application and extend the period of availability to plants. Conservation systems are tailored to achieve these objectives based on a set of techniques to improve soil conditions, namely, no tillage combined with crop rotation and the use of soil cover crops for straw production, thereby raising the total $\mathrm{N}$ level in the top soil layers (Punormo et al., 2000, D'Haene et al., 2008, Weber \& Mielniczuk, 2009).

According to Amado et al. (1999) and Sá et al. (2001), the reduction of soil mobilization intensity improves total $\mathrm{N}$ accumulation in the top soil layer in the conservation systems, compared to conventional tillage (CT) systems, reducing losses through immobilization and gradual release of the nutrient by microorganisms, which is interesting from the point of view of biological activity and reduction of environmental risks.

Due to the complexity of $\mathrm{N}$ dynamics in the soil, the mineralization and nitrification rates are considered indicators of fertility. According to Purnomo et al. (2000) and Siqueira Neto (2003), the higher net $\mathrm{N}$ mineralization and nitrification rates and greater quantities of ammonium $\left(\mathrm{NH}_{4}{ }^{+}\right)$in the
0-2.5 cm layer of the no-tillage system (NT) are associated with the crop residues left on the soil surface.

The quantity and quality of residues are influenced by the soil $\mathrm{pH}$, an important factor in the process of soil organic matter (SOM) mineralization. This process is exclusively microbiological (Silva et al., 1994) and can limit the nitrification rates and distribution of $\mathrm{N}^{-\mathrm{NH}_{4}}{ }^{+}$and $\mathrm{N}-\mathrm{NO}_{3}$ - in the soil profile (Camargo et al., 1997; Rosolem et al., 2003). Climatic conditions are also critical factors that commonly determine the transformation of SOM and, consequently, mineralization and nitrification of soil N (Sierra, 1997). Variations in temperature and moisture modify the behavior of soil $\mathrm{N}$ and may significantly affect its availability at the soil surface (Punormo et al., 2000).

The objective of this study was to determine the net mineralization and nitrification rates of $\mathrm{N}$ in the soil and their relationship to $\mathrm{pH}$ in long-term experiments in areas under different management systems to contribute to strategies for environmental sustainability.

\section{MATERIALS AND METHODS}

The experiment was conducted at the $\mathrm{ABC}$ Foundation Experimental Station, in areas where soil 
management systems (SMSs) had been adopted as of 1988. The experimental station is located in the municipality of Ponta Grossa, State of Paraná, on the second plateau, in the central South region of the State (25 $20^{\prime} \mathrm{S}$ and $50^{\circ} 20^{\prime} \mathrm{W}, 980 \mathrm{~m}$ asl). The climate of the experimental area is humid subtropical (Cfb Köppen classification), with cool summers and frost in winter. Average annual rainfall and temperature are $1545 \mathrm{~mm}$ and $20^{\circ} \mathrm{C}$, respectively (IAPAR, 1994). To understand changes in the $\mathrm{N}$ dynamics and their relationship to the evaluated properties, the climatic conditions during the sampling period were analyzed based on the historical cycle of the region (Figure 1).

The soil was classified as typical Red Latosol (Embrapa, 2006), and is deep, well-structured and drained, with a clayey texture. The soil was derived from reworked sandstone material from the Furnas formation and shale from the Ponta Grossa formation, of the Devonian Period. In October 2003, soil samples were collected from the $0-2.5,2.5-5$ and $5-10 \mathrm{~cm}$ layers for soil fertility analysis. The samples were air-dried, homogenized and sieved through $2 \mathrm{~mm}$ mesh for subsequent analysis of $\mathrm{pH}, \mathrm{Ca}^{2+}, \mathrm{Mg}^{2+}$ and $\mathrm{Al}^{3+}$ (extracted with $\left.\mathrm{KCl}\right), \mathrm{H}^{+}+\mathrm{Al}^{3+}, \mathrm{K}^{+}$and $\mathrm{P}$ (extracted by Mehlich-1) according to Embrapa (1997) (Table 1).

A randomized complete block design was used in a subdivided plot scheme with three replications. The plots consisted of the following SMSs: 1) conventional tillage (CT), by subsoiling to a depth of $20 \mathrm{~cm}$ followed by two disk harrowings; 2) minimum tillage (MT), by a chisel plow reaching to a depth of $30 \mathrm{~cm}$ followed by disk harrowing; 3) no-tillage with chisel plow $\left(\mathrm{NT}_{\mathrm{CH}}\right)$, which consisted of direct planting on crop residues left on the soil surface plus chisel plowing to a depth of $30 \mathrm{~cm}$ every three years; and 4) continuous notillage (CNT), consisting of continuous direct planting on crop residues left on the soil surface. To evaluate the inorganic $\mathrm{N}$ dynamics, samples were collected from subplots on 11 sampling dates $\left(\mathrm{T}_{1}\right.$ to $\left.\mathrm{T}_{11}\right)$. The (a)

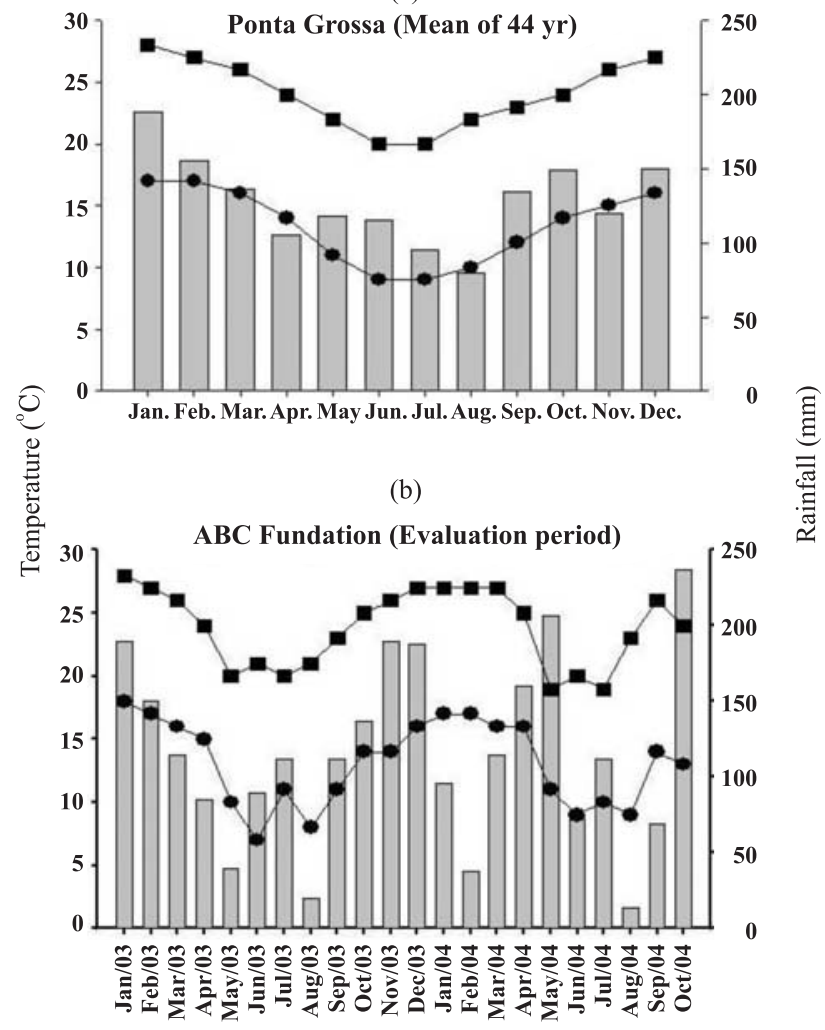

Figure 1. Monthly rainfall distribution (bars) with maximum ( Tmax) and minimum (- Tmin) temperatures. Historical data for Ponta Grossa (a) and for the period from January 2003 to October 2004 (b).

dimensions of each experimental unit were $8.3 \times 25 \mathrm{~m}$, totaling $2500 \mathrm{~m}^{2}$. To estimate the residue input into the soil by each SMS, the yield of the crops planted during the experiment (soybean in the 2003/2004 and wheat in the 2004 growing seasons) are presented (Table 2).

Table 1. Chemical characterization of the soil under the different soil management systems (SMSs) before the beginning of the experiment

\begin{tabular}{|c|c|c|c|c|c|c|c|c|c|c|c|}
\hline $\operatorname{SMSs}^{(1)}$ & Layer & pH $\mathrm{CaCl}_{2}$ & $\mathbf{H}+\mathbf{A l}$ & $\mathrm{Al}^{3+}$ & $\mathrm{Ca}^{2+}$ & $\mathrm{Mg}^{2+}$ & $\mathbf{K}^{+}$ & CEC & $\mathbf{P}$ & C & $\mathbf{V}$ \\
\hline \multicolumn{3}{|c|}{$\mathrm{cm}$} & \multicolumn{6}{|c|}{$-\mathrm{cmol}_{\mathrm{c}} \mathrm{dm}^{-3}$} & $\mathrm{mg} \mathrm{dm}^{-3}$ & $\mathrm{~g} \mathrm{dm}^{-3}$ & $\%$ \\
\hline CNT & $\begin{array}{c}0-2.5 \\
2.5-5 \\
5-10\end{array}$ & $\begin{array}{l}5.9 \\
5.6 \\
5.6\end{array}$ & $\begin{array}{l}4.8 \\
6.5 \\
6.6\end{array}$ & $\begin{array}{l}0.00 \\
0.07 \\
0.07\end{array}$ & $\begin{array}{l}5.9 \\
5.2 \\
4.6\end{array}$ & $\begin{array}{l}3.1 \\
2.5 \\
2.3\end{array}$ & $\begin{array}{l}0.91 \\
0.55 \\
0.40\end{array}$ & $\begin{array}{l}14.7 \\
14.8 \\
13.9\end{array}$ & $\begin{array}{l}27.2 \\
17.3 \\
20.9\end{array}$ & $\begin{array}{l}48.7 \\
37.3 \\
30.0\end{array}$ & $\begin{array}{l}66.7 \\
56.0 \\
52.7\end{array}$ \\
\hline $\mathrm{NT}_{\mathrm{CH}}$ & $\begin{array}{c}0-2.5 \\
2.5-5 \\
5-10\end{array}$ & $\begin{array}{l}5.5 \\
5.3 \\
5.2\end{array}$ & $\begin{array}{l}5.8 \\
6.6 \\
6.9\end{array}$ & $\begin{array}{l}0.00 \\
0.00 \\
0.00\end{array}$ & $\begin{array}{l}4.6 \\
4.6 \\
4.2\end{array}$ & $\begin{array}{l}2.7 \\
2.2 \\
2.0\end{array}$ & $\begin{array}{l}0.80 \\
0.42 \\
0.27\end{array}$ & $\begin{array}{l}13.9 \\
13.8 \\
13.3\end{array}$ & $\begin{array}{l}14.0 \\
13.4 \\
11.0\end{array}$ & $\begin{array}{l}42.3 \\
39.0 \\
35.0\end{array}$ & $\begin{array}{l}58.7 \\
52.7 \\
48.7\end{array}$ \\
\hline $\mathrm{MT}$ & $\begin{array}{c}0-2.5 \\
2.5-5 \\
5-10\end{array}$ & $\begin{array}{l}5.6 \\
5.5 \\
5.4\end{array}$ & $\begin{array}{l}5.4 \\
5.9 \\
6.4\end{array}$ & $\begin{array}{l}0.00 \\
0.00 \\
0.00\end{array}$ & $\begin{array}{l}4.8 \\
4.8 \\
4.7\end{array}$ & $\begin{array}{l}2.5 \\
2.5 \\
2.5\end{array}$ & $\begin{array}{l}0.74 \\
0.40 \\
0.28\end{array}$ & $\begin{array}{l}13.5 \\
13.5 \\
13.8\end{array}$ & $\begin{array}{l}9.4 \\
9.0 \\
7.5\end{array}$ & $\begin{array}{l}37.0 \\
33.7 \\
27.7\end{array}$ & $\begin{array}{l}59.7 \\
56.7 \\
54.0\end{array}$ \\
\hline $\mathrm{CT}$ & $\begin{array}{c}0-2.5 \\
2.5-5 \\
5-10\end{array}$ & $\begin{array}{l}5.7 \\
5.6 \\
5.4\end{array}$ & $\begin{array}{l}5.0 \\
5.7 \\
5.9\end{array}$ & $\begin{array}{l}0.00 \\
0.00 \\
0.00\end{array}$ & $\begin{array}{l}4.6 \\
4.4 \\
4.2\end{array}$ & $\begin{array}{l}2.7 \\
2.3 \\
2.0\end{array}$ & $\begin{array}{l}0.80 \\
0.51 \\
0.35\end{array}$ & $\begin{array}{l}13.1 \\
12.9 \\
12.5\end{array}$ & $\begin{array}{l}8.5 \\
7.0 \\
5.7\end{array}$ & $\begin{array}{l}34.3 \\
33.0 \\
31.3\end{array}$ & $\begin{array}{l}61.7 \\
56.3 \\
52.0\end{array}$ \\
\hline
\end{tabular}

(1) $\mathrm{CNT}$ : continuous no-tillage; $\mathrm{NT}_{\mathrm{CH}}$ : no-tillage with chisel plow; MT: minimum tillage; and $\mathrm{CT}_{1}$ conventional tillage. 
Table 2. Soybean (harvest 2003/2004) and wheat (harvest 2004) yield in the experimental area under continuous no-tillage (CNT), no tillage with chisel plow $\left(\mathrm{NT}_{\mathrm{CH}}\right)$, minimum tillage $(\mathrm{MT})$ and conventional tillage (CT)

\begin{tabular}{llllll}
\hline \multirow{2}{*}{ Crop } & \multirow{2}{*}{ Season } & \multicolumn{5}{c}{ Soil management systems } \\
\cline { 3 - 6 } & & $\mathbf{C N T}$ & $\mathbf{N T}_{\mathbf{C H}}$ & $\mathbf{M T}$ & $\mathbf{C T}$ \\
\cline { 3 - 6 } & & \multicolumn{5}{c}{$\mathrm{kg} \mathrm{ha}^{-1}$} \\
Soybean & $2003 / 2004$ & 3883 & 3453 & 3759 & 3567 \\
Wheat & 2004 & 5453 & 5553 & 5241 & 4879 \\
\hline
\end{tabular}

The study was initiated on white oat residues (Avena sativa - Variety OR3), which were cut and chopped with a knife roller, began in October 2003. In the same period, the soil in the CT treatment was turned over by plowing, followed by two disk harrowings, and in the MT treatment, chiseling was applied followed by two disk harrowings. On November 10, 2003, soybean (Glycine $\max$ ) variety CD-206 was sown with $0.4 \mathrm{~m}$ spacing between rows and an average of 14 plants per meter. For base fertilization, $160 \mathrm{~kg} \mathrm{ha}^{-1}$ of the fertilizer NPK 0-2525 were used.
In May 2004, before sowing wheat (Triticum aestivum), the soil was prepared for the CT and MT treatments, as described above. The wheat variety CD-105 was sown on June 2, 2004, with in rows spaced $0.17 \mathrm{~m}$ apart, at a sowing density of $140 \mathrm{~kg} \mathrm{ha}^{-1}$. The fertilizer (8-30-20 NPK) was applied in the planting furrow at $300 \mathrm{~kg} \mathrm{ha}^{-1}$, and $\mathrm{N}$ in the form of urea was used as top dressing at $90 \mathrm{~kg} \mathrm{ha}^{-1} \mathrm{~N}$ during the full tillering stage in the form of urea.

To determine the net mineralization and nitrification rates as well as the moisture and soil $\mathrm{pH}, 11$ soil was sampled at depths of $0-2.5,2.5-5$ and 5-10 cm, from October 2003 (immediately after white oat management) to September 2004. The samples from the $0-2.5$ and $2.5-5 \mathrm{~cm}$ layers were collected using a spatula. Three subsamples collected from each plot were mixed to a composite sample of the cited plots and depths. For the 5-10 cm layer, the samples were collected with a stainless steel $2.0 \mathrm{~cm}$ internal diameter probe (Bravifer ${ }^{\circledR}$, Piracicaba-SP).

The soil samples for determination of the soil inorganic $\mathrm{N}\left(\mathrm{N}-\mathrm{NH}_{4}{ }^{+}\right.$and $\left.\mathrm{N}-\mathrm{NO}_{3}{ }^{-}\right)$were prepared immediately upon arrival at the laboratory on the day of the collection. The roots were removed from the soil samples, and the inorganic $\mathrm{N}$ concentration was

Table 3. Soil pH (in water) as a function of the soil management systems (treatments) in the layers 0-2.5, 2.55, 5-10 and 10-20 cm, from October 2003 to September 2004

\begin{tabular}{|c|c|c|c|c|c|c|c|c|c|c|}
\hline \multirow{2}{*}{ Month } & \multicolumn{5}{|c|}{ Soil management system ${ }^{(1)}$} & \multicolumn{5}{|c|}{ Soil management system } \\
\hline & CNT & $\mathbf{N T}_{\mathbf{C H}}$ & MT & $\mathbf{C T}$ & $\overline{\text { Mean }}$ & CNT & $\mathbf{N T}_{\mathrm{CH}}$ & MT & $\mathrm{CT}$ & $\overline{\text { Mean }}$ \\
\hline & \multicolumn{5}{|c|}{ Depth $(0-2.5 \mathrm{~cm})$} & \multicolumn{5}{|c|}{ Depth $(2.5-5 \mathrm{~cm})$} \\
\hline Oct/03 & $6.53 \mathrm{Abc}(2)$ & $6.08 \mathrm{Bcd}$ & $6.03 \mathrm{Bd}$ & 6.03 Bcde & $6.16 \mathrm{~d}$ & 6.40 Ade & $5.95 \mathrm{Bde}$ & $6.0 \mathrm{Bcd}$ & 6.10 Bbcd & $6.11 \mathrm{def}$ \\
\hline Nov/03 & $6.58 \mathrm{Abc}$ & $5.95 \mathrm{Bde}$ & $6.08 \mathrm{Bcd}$ & $6.12 \mathrm{Bbcd}$ & $6.18 \mathrm{~cd}$ & $6.68 \mathrm{Aab}$ & $5.84 \mathrm{Ce}$ & $6.05 \mathrm{Bcd}$ & $6.13 \mathrm{Bbcd}$ & $6.17 \mathrm{cde}$ \\
\hline $\mathrm{Jan} / 04$ & $6.65 \mathrm{Ab}$ & $6.21 \mathrm{Bbc}$ & $6.12 \mathrm{Bcd}$ & $6.16 \mathrm{Bbcd}$ & $6.28 \mathrm{c}$ & $6.67 \mathrm{Abc}$ & 6.29 Bab & $6.09 \mathrm{Bcd}$ & 6.17 Bbcd & $6.30 \mathrm{bc}$ \\
\hline $\mathrm{Feb} / 04$ & $6.53 \mathrm{Abc}$ & $5.96 \mathrm{Cde}$ & 6.16 BCbcd & $6.26 \mathrm{Bb}$ & $6.23 \mathrm{~cd}$ & 6.46 Acd & $6.06 \mathrm{Bcd}$ & 6.20 Babc & $6.23 \mathrm{ABbc}$ & $6.24 \mathrm{bcd}$ \\
\hline Mar/04 & $6.54 \mathrm{Abc}$ & 6.01 Bcde & $6.06 \mathrm{Bcd}$ & $5.95 \mathrm{Bde}$ & $6.14 \mathrm{de}$ & $6.47 \mathrm{Abcd}$ & 5.90 Bde & $5.90 \mathrm{Bde}$ & $5.97 \mathrm{Bde}$ & $6.06 \mathrm{efg}$ \\
\hline Apr/04 & $6.98 \mathrm{Aa}$ & $6.47 \mathrm{Ba}$ & $6.42 \mathrm{Ba}$ & $6.57 \mathrm{Ba}$ & $6.61 \mathrm{a}$ & $6.89 \mathrm{Aa}$ & $6.37 \mathrm{Ba}$ & $6.39 \mathrm{Ba}$ & $6.55 \mathrm{Ba}$ & $6.55 \mathrm{a}$ \\
\hline May/04 & $6.56 \mathrm{Abc}$ & $6.21 \mathrm{Bbc}$ & $6.18 \mathrm{Bbcd}$ & 6.04 Bcde & $6.25 \mathrm{~cd}$ & 6.45 Ade & $6.06 \mathrm{Bcd}$ & $6.14 \mathrm{Bbc}$ & $6.05 \mathrm{Bcd}$ & $6.17 \mathrm{bcde}$ \\
\hline Jun/04 & $6.40 \mathrm{Ac}$ & $5.84 \mathrm{Be}$ & $6.01 \mathrm{Bd}$ & $5.87 \mathrm{Be}$ & 6.03 ef & $6.31 \mathrm{Ae}$ & $5.79 \mathrm{Ce}$ & $6.01 \mathrm{Bcd}$ & $5.80 \mathrm{Ce}$ & $5.98 \mathrm{fg}$ \\
\hline $\mathrm{Jul} / 04$ & $6.17 \mathrm{Ad}$ & 5.93 Ade & $5.78 \mathrm{Be}$ & $5.84 \mathrm{Be}$ & $5.93 \mathrm{f}$ & 6.39 Ade & $5.77 \mathrm{Be}$ & $5.72 \mathrm{Be}$ & $5.81 \mathrm{Be}$ & $5.92 \mathrm{~g}$ \\
\hline Aug/04 & $6.71 \mathrm{Ab}$ & 6.38 Bab & 6.27 Babc & $6.26 \mathrm{Bb}$ & $6.41 \mathrm{c}$ & $6.55 \mathrm{Abcd}$ & 6.17 Babc & 6.33 $\mathrm{Bab}$ & $6.27 \mathrm{Bb}$ & $6.33 \mathrm{~b}$ \\
\hline Sep/04 & $6.93 \mathrm{Aa}$ & $6.51 \mathrm{Ba}$ & 6.36 BCab & $6.24 \mathrm{Cbc}$ & $6.51 \mathrm{ab}$ & $6.55 \mathrm{Abcd}$ & $6.11 \mathrm{Bbcd}$ & $6.01 \mathrm{Bcd}$ & $6.05 \mathrm{Bcd}$ & $6.18 \mathrm{bcde}$ \\
\hline Mean & $6.60 \mathrm{~A}$ & $6.14 \mathrm{~B}$ & $6.13 \mathrm{~B}$ & $6.12 \mathrm{~B}$ & & $6.53 \mathrm{~A}$ & $6.03 \mathrm{~A}$ & $6.08 \mathrm{~A}$ & $6.10 \mathrm{~A}$ & \\
\hline \multirow[t]{2}{*}{ CV (\%) } & 14.2 & & & & & 18.0 & & & & \\
\hline & \multicolumn{5}{|c|}{ Depth $(5-10 \mathrm{~cm})$} & \multicolumn{5}{|c|}{ Depth $(10-20 \mathrm{~cm})$} \\
\hline Oct/03 & 6.37 Aef & 5.96 Bcdef & $6.00 \mathrm{Bcd}$ & $6.09 \mathrm{Bbcd}$ & $6.11 \mathrm{de}$ & 6.36 Ade & 5.92 Bde & $6.03 \mathrm{Bb}$ & 6.06 Bde & $6.09 \mathrm{def}$ \\
\hline Nov/03 & $6.79 \mathrm{Aab}$ & 5.91 Bdef & $6.04 \mathrm{Bbcd}$ & $6.08 \mathrm{Bbcd}$ & 6.20 bcde & $6.53 \mathrm{Ad}$ & 5.96 Bde & $6.19 \mathrm{Bb}$ & 6.17 Bcde & $6.21 \mathrm{~cd}$ \\
\hline $\mathrm{Jan} / 04$ & 6.68 Aabc & $6.21 \mathrm{Bb}$ & $6.12 \mathrm{Bbc}$ & $6.18 \mathrm{Bbc}$ & $6.30 \mathrm{~b}$ & 6.66 Aabc & $6.23 \mathrm{Bcd}$ & $6.23 \mathrm{Bb}$ & $6.24 \mathrm{Bbc}$ & $6.34 \mathrm{bc}$ \\
\hline $\mathrm{Feb} / 04$ & 6.50 Acde & 6.10 Bbcd & 6.20 Bab & $6.23 \mathrm{Bbc}$ & $6.25 \mathrm{bc}$ & 6.43 Acd & 6.36 Aab & $6.23 \mathrm{Ab}$ & $6.36 \mathrm{Abc}$ & $6.35 \mathrm{bc}$ \\
\hline $\mathrm{Mar} / 04$ & $6.48 \mathrm{Ad}$ & 5.99 Bcde & 5.94 Bcde & $5.98 \mathrm{Bde}$ & $6.10 \mathrm{e}$ & 6.67 Aab & 6.38 $\mathrm{Bab}$ & $6.12 \mathrm{Cb}$ & 6.21 BCbcde & $6.34 \mathrm{bc}$ \\
\hline Apr/04 & $6.81 \mathrm{Aa}$ & $6.46 \mathrm{Ba}$ & $6.32 \mathrm{Ba}$ & $6.47 \mathrm{Ba}$ & $6.51 \mathrm{a}$ & $6.80 \mathrm{Aa}$ & $6.54 \mathrm{Ba}$ & $6.62 \mathrm{ABa}$ & $6.65 \mathrm{ABa}$ & $6.65 \mathrm{a}$ \\
\hline May/04 & 6.48 Ade & 6.05 Bbcde & $6.09 \mathrm{Bbcd}$ & 6.05 Bcde & 6.17 cde & $6.49 \mathrm{Abcd}$ & $6.26 \mathrm{ABbc}$ & $6.10 \mathrm{BCb}$ & $5.99 \mathrm{Cef}$ & $6.21 \mathrm{~cd}$ \\
\hline Jun/04 & $6.28 \mathrm{Af}$ & $5.78 \mathrm{BCf}$ & 5.91 Bde & $5.70 \mathrm{Cf}$ & $5.92 \mathrm{f}$ & $6.13 \mathrm{Ae}$ & $5.74 \mathrm{Be}$ & $6.08 \mathrm{Ab}$ & $5.81 \mathrm{Bf}$ & $5.94 \mathrm{f}$ \\
\hline Jul/04 & $6.08 \mathrm{Ag}$ & 5.91 ABdef & $5.77 \mathrm{Be}$ & $5.87 \mathrm{Bef}$ & $5.91 \mathrm{f}$ & $6.15 \mathrm{Ae}$ & $5.99 \mathrm{Ad}$ & $6.01 \mathrm{Ab}$ & 6.15 Adef & $6.04 \mathrm{ef}$ \\
\hline Aug/04 & 6.56 Acde & $6.23 \mathrm{Bb}$ & 6.21 Bab & $6.26 \mathrm{Bb}$ & $6.31 \mathrm{~b}$ & 6.54 Abcd & 6.38 Aab & $6.49 \mathrm{Aa}$ & $6.41 \mathrm{Ab}$ & $6.45 \mathrm{~b}$ \\
\hline Sep/04 & $6.61 \mathrm{Abcd}$ & $6.13 \mathrm{Bbc}$ & $6.03 \mathrm{Bbcd}$ & $6.13 \mathrm{Bbcd}$ & $6.23 \mathrm{bcd}$ & $6.63 \mathrm{Aabc}$ & $6.03 \mathrm{Bcd}$ & $6.00 \mathrm{Bb}$ & 6.04 Bde & $6.17 \mathrm{de}$ \\
\hline Mean & $6.51 \mathrm{~A}$ & $6.06 \mathrm{~A}$ & $6.06 \mathrm{~A}$ & $6.09 \mathrm{~A}$ & & $6.49 \mathrm{~A}$ & $6.16 \mathrm{~A}$ & $6.19 \mathrm{~A}$ & $6.18 \mathrm{~A}$ & \\
\hline CV (\%) & 16.1 & & & & & 13.5 & & & & \\
\hline
\end{tabular}

(1) The following abbreviations are used: CNT, continuous no-tillage; $\mathrm{NT}_{\mathrm{CH}}$, no-tillage with chisel plow; MT, minimum tillage; and $\mathrm{CT}$, conventional tillage. ${ }^{(2)}$ Capital letters in the rows comparing soil management systems and lowercase letters in the columns comparing collection times indicate values that do not differ among themselves by Student's LSD test ( $p<0.1$ ). 
determined in soil extracts prepared by extraction with a $2 \mathrm{~mol} \mathrm{~L}^{-1} \mathrm{KCl}$ solution for $24 \mathrm{~h}$, at a soil:solution ratio of $5: 1$. These extracts were filtered and stored

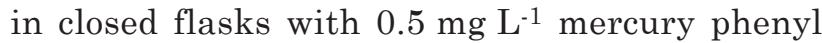
acetate (time $=0$ days of incubation) to inhibit nitrification. Next, approximately $100 \mathrm{~g}$ of soil was incubated for seven days at room temperature in the laboratory for another $\mathrm{KCl}$ extraction (time $=$ seven days of incubation), as described for time $=0$ (Piccolo et al., 1994). A sample of approximately $5 \mathrm{~g}$ of soil was dried to constant weight at $105^{\circ} \mathrm{C}$ for gravimetric moisture determination.

The $\mathrm{N}-\mathrm{NH}_{4}{ }^{+}$and $\mathrm{N}-\mathrm{NO}_{3}{ }^{-}$concentrations in the extracts ( $\mathrm{t}=0$ and $\mathrm{t}=7$ days) were determined by an automatic continuous flow injection system (FIA), as described by Alves et al. (1994), coupled to a digital

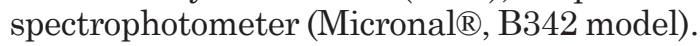

The net $\mathrm{N}$ mineralization rate was calculated as the variation in the $\mathrm{N}$ concentration $\left(\mathrm{N}-\mathrm{NH}_{4}{ }^{+}+\mathrm{N}\right.$ $\mathrm{NO}_{3}{ }^{-}$) during incubation (t7-t0) (Equation 1). The net $\mathrm{N}$ nitrification rate corresponds to the final subtracted from the initial $\mathrm{N}-\mathrm{NO}_{3}$ - content during the incubation period (Equation 2). The net mineralization and nitrification rates were expressed in $\mathrm{kg} \mathrm{ha}^{-1}$ day $^{-1}$ with a correction for the density of the different layers in the soil profile.

$$
\begin{aligned}
& \text { Mineralization rate }=\frac{\left({\mathrm{N}-\mathrm{NH}_{4}}^{+}+\mathrm{N}-\mathrm{NO}_{3}^{-}\right) \text {final }-\left(\mathrm{N}_{-} \mathrm{NH}_{4}^{+}+\mathrm{N}^{+} \mathrm{NO}_{3}^{-}\right) \text {initial }}{\text { Incubation time (day) }}
\end{aligned}
$$

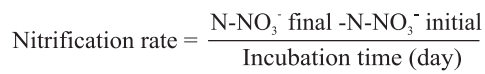

Due to human error, in September 2004, the N$\mathrm{NH}_{4}{ }^{+}$reading was lost. Therefore, the mineralization rates were calculated and shown only until August 2004.

The soil $\mathrm{pH}$ was determined in water, using a soil:water ratio of $1: 2.5$ and a 10 min shaking time (Embrapa, 1997).

The results were subjected to analysis of variance (ANOVA), and depending on the significance level, the Student's t-test and one-way ANOVA followed by Least Significant Difference Test (LSD) post hoc analysis was used to compare means at the $5 \%$ significance level $(\mathrm{p}<0.05)$ to detect differences between the treatments.

\section{RESULTS AND DISCUSSION}

\section{Net mineralization and nitrification rates}

The average net soil $\mathrm{N}$ mineralization and nitrification rates differed significanctly between the SMSs. In the treatments with $\mathrm{CNT}$ and $\mathrm{NT}_{\mathrm{CH}}$ management, the mineralization rate in the $0-2.5 \mathrm{~cm}$ layer was higher than in the MT and CT systems, while the nitrification rate was higher in the 2.5$5 \mathrm{~cm}$ layer (Figures 2 and 3). According to Groffman (1984), elevated nitrification rates can be attributed to the accumulation of labile organic compounds combined with a much slower and more continuous process of organic N mineralization (Alvarez et al., 1998). Muruganandam et al. (2010) also reported higher $\mathrm{N}$ mineralization and nitrification rates in a NT than a CT management. They found that the high rates of $\mathrm{N}$ transformation in $\mathrm{NT}$ were related to the greater microbial population in this system. Muruganandam et al. (2009) suggested that NT also increases the activity of enzymes involved in $\mathrm{N}$ mineralization due to the increased proportion of fungus in the microbial community in this system. The lower mineralization and nitrification rates in the CT system can also be explained, in part, by a more accelerated decomposition due to the more

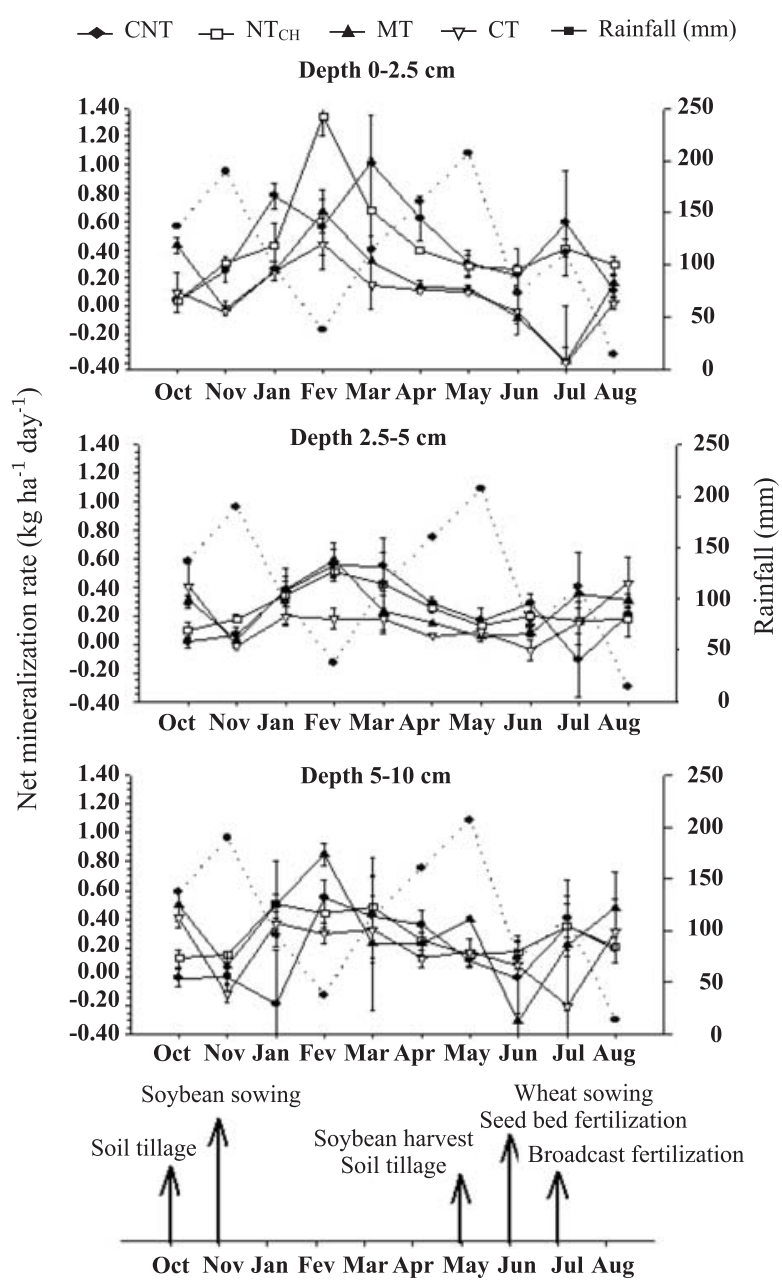

Figure 2. Net mineralization rates in the 0-2.5, 2.5-5 and 5-10 cm layers under continuous no-tillage (CNT), no-tillage with chisel plow $\left(\mathrm{NT}_{\mathrm{CH}}\right)$, minimum tillage (MT) and conventional tillage (CT) from October 2003 to August 2004. The results represent the average \pm the error. 
intense attack of microorganisms on the incorporated organic material and the shorter period of $\mathrm{N}$ mineralization (Souza \& Melo, 2000).

In the $5-10 \mathrm{~cm}$ layer, the mineralization and nitrification rates did not differ between the management systems (Figures 2 and 3). This finding demonstrates that the transformation processes are closely related to the upper centimeters of the soil, which are more influenced by the crop residues. Additionally, soil layers are stratified, and the SOM content decreases from the surface to the deeper layers.

In October 2003 (the first month of evaluation), the mineralization and nitrification rates were higher in the MT and CT systems in all layers, although differences were only observed in the $2.5-5 \mathrm{~cm}$ layer (Figures 2 and 3). This increase in the mineralization rate is associated with soil tilling after the winter crop in these management systems, increasing the decomposition of organic material and $\mathrm{N}$ nitrification (Sá, 1993). Under other climatic conditions, Drinkwater et al. (2000) observed N mineralization over a shorter period and the possibility of leaching of this mineralized $\mathrm{N}$ during rainy periods.

In contrast, in the $\mathrm{CNT}$ and $\mathrm{NT}_{\mathrm{CH}}$ management systems, lower mineralization and nitrification rates were observed. In this period, soybean followed the white oat crop with a high phytomass $\mathrm{C} / \mathrm{N}$ ratio, suggesting temporary $\mathrm{N}$ immobilization by the microorganisms. This observation is relevant because this crop combination is widely used by farmers in southern Brazil. Green \& Blackmer (1995) and Jiggou \& Bakken (1997) observed a significant potential for $\mathrm{N}$ immobilization in the soil with the application of crop residues with a high $\mathrm{C} / \mathrm{N}$ ratio in the early stages of soybean development. In this stage, soybean absorbs $\mathrm{N}$ from the soil for its initial development, until N-fixing organisms form root nodules that provide $\mathrm{N}$ for the crop development.

From January to April 2004, the mineralization and nitrification rates were higher in the conservation systems than under $\mathrm{CT}$ in the $0-2.5$ and $2.5-5 \mathrm{~cm}$ layers (Figures 2 and 3 ). In this period, these rates can be associated with the phytomass of the preceding crop left on the soil surface and leaf drop from the plant lower third due to senescence. These leaves are more easily degradable (lower $\mathrm{C} / \mathrm{N}$ ratio) due to their higher content of protein, amino acids, nucleic acids and other easily decomposable compounds (Mengel, 1996). Furthermore, factors such as higher temperature and $\mathrm{pH}$ and the maintenance of appropriate soil moisture in the conservation systems, even with low rainfall (Figure 1), favor the soil microbiota, which raises the N quantity (Groffman, 1984; Amado et al., 2001; Sá et al., 2001). Thus, Liebig et al. (2002) observed greater nutrient cycling efficiency and the potential for soil $\mathrm{N}$ mineralization in crop sequences involving leguminous plants.
In February 2004, four months after starting evaluations, higher net mineralization and nitrification rates were observed for the $\mathrm{NT}_{\mathrm{CH}}$ management system than for the other SMSs in the $0-2.5 \mathrm{~cm}$ layer (Figures 2 and 3). In this month, the amount of rainfall was one of the lowest of the evaluation period and much lower than the historical average recorded in the region (Figure 1). The soil of the $\mathrm{NT}_{\mathrm{CH}}$ treatment had been chiseled two years earlier, and the rearrangement of the soil structure had probably not been consolidated in that period (Six et al., 1999), leaving empty spaces and macropores and favoring the development of microbial biomass niches, resulting in higher net mineralization and nitrification rates (Venzke-Son, 1999).

Although the soil preparation for the MT and CT plots was completed in May 2004, no significant

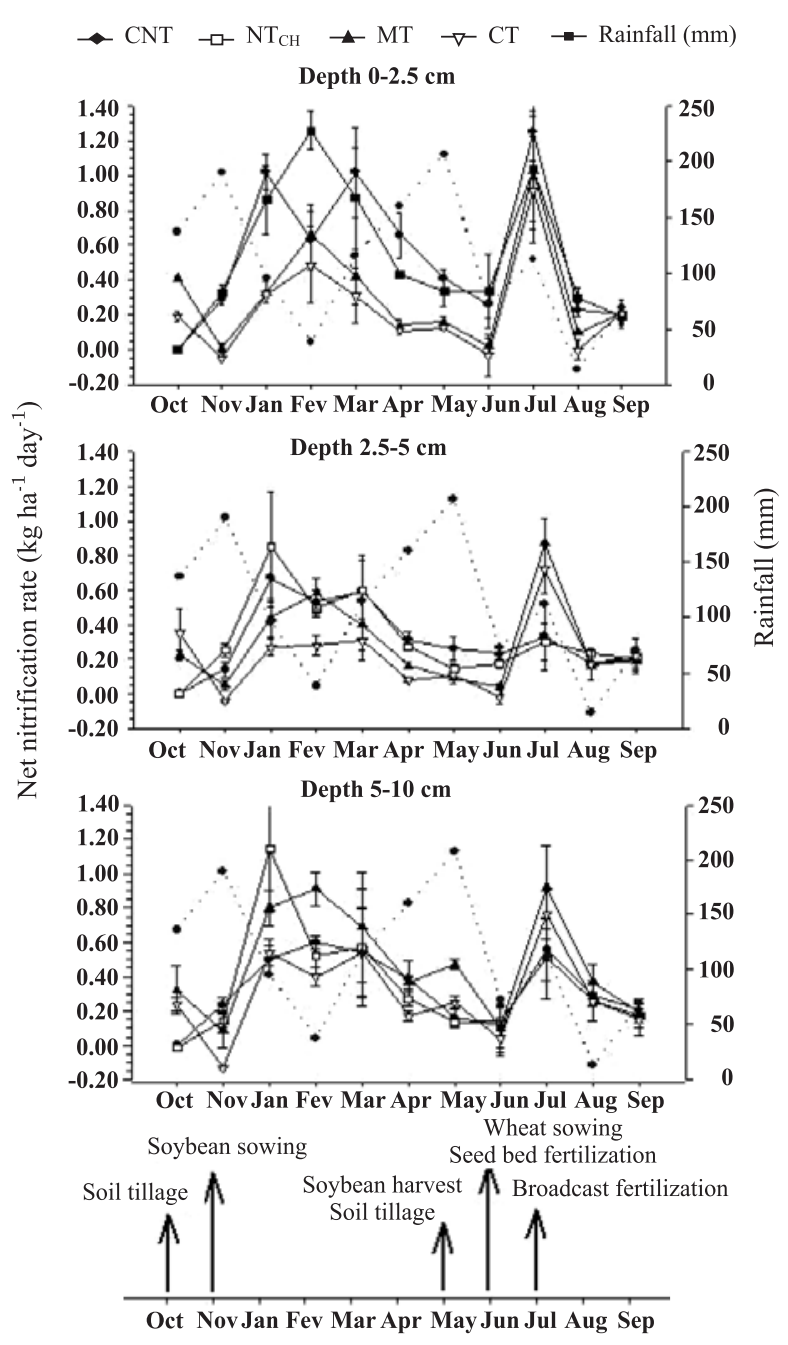

Figure 3. Net nitrification rates in the $0-2.5,2.5-5$ and $5-10 \mathrm{~cm}$ layers under continuous no-tillage (CNT), no-tillage with chisel plow $\left(\mathrm{NT}_{\mathrm{CH}}\right)$, minimum tillage (MT) and conventional tillage (CT) from October 2003 to August 2004. The results represent the average \pm the error. 
differences in the mineralization and nitrification rates were observed between the SMSs in any of the layers (Figures 2 and 3). This can be explained by the fact that sampling was carried out one day after soil management and by the marked temperature drop in the period (Figure 1) and high rainfall in the days before. In this case, the microbial activity to decompose the post-harvest soybean residues was not stimulated, and the high rainfall observed in this month may also have inhibited the decomposer activity and caused leaching, mainly of $\mathrm{N}-\mathrm{NO}_{3}$ - (Drinkwater et al., 2000).

In June, the mineralization and nitrification rates were higher in the conservation systems in the 0 2.5, 2.5-5 and 5-10 cm layers, although the difference was only observed in comparison with the CNT system in the 2.5-5 cm layer (Figures 2 and 3). The lower nitrification rate in CT may have been due to lower $\mathrm{N}$ availability in the system, which would have caused a temporary immobilization of this $\mathrm{N}$ in the microbial biomass after wheat fertilization at sowing.

In July, nitrification rates in the MT and CT were higher than in the CNT and $\mathrm{NT}_{\mathrm{CH}}$ systems (Figure 3). In this month, in addition to the previous $\mathrm{N}$ fertilization at sowing, topdressing was applied (200 kg ha-1 urea), according to Green \& Blackmaer (1995). The immobilization period tends to decrease with increased fertilization, suggesting an increase in $\mathrm{N}$ in the biomass of the MT and CT systems. Moreover, better soil aeration and moisture conditions due to higher rainfall in this month than the previous raised the nitrification rate, demonstrating the activity of the nitrifying microorganisms in the soil. Reinertsen et al. (1984) and Mansson \& FalkengrenGrerup (2002) also showed that the addition of $\mathrm{N}$ stimulates the decomposition of soil incorporated residues.

In July 2004, the mineralization rates in the $0-$ $2.5 \mathrm{~cm}$ layer decreased in the MT and CT compared to the CNT and $\mathrm{NT}_{\mathrm{CH}}$ systems. In the 5-10 cm layer, the mineralization rate was lowest in the CT system, but did not differ from the other management systems (Figure 2). These lower rates probably occurred due to the immobilization of $\mathrm{N}$ fertilizer by soil microorganisms, which influenced the mineralization of organic $\mathrm{N}$ negatively, supporting the results of Carpenter-Boggs et al. (2000), obtained in crop rotation systems involving corn and soybean.

One month after side dressing (August 2004), the mineralization and nitrification rates were not significantly different between the SMSs, although the nitrification rate was still reduced (Figure 3 ). Rapid nitrification of the fertilizer within 30 days was observed, although the soil was sampled only once in this month. Thus, the $\mathrm{N}$ use efficiency of wheat was low, when applied in large amounts. In September 2004 , one of the lowest nitrification rates was observed in all evaluated layers (Figure 3), correlated with the reduced rainfall (August and September 2004) that may have interfered with the nitrification activity of the microorganisms. Robertson \& Groffman (2007) reported that microbial activity is directly related to temperature and soil moisture, which increases with temperature and reaches an optimum level at intermediate moisture. In this case, the limiting factor for microbial activity under low rainfall would be the lack of water; however under high rainfall, the limiting factor would be the lack of air as the soil becomes waterlogged.

\section{Flow of mineral $\mathrm{N}$ in relation to soil acidity}

Comparing the averages of each evaluated month, the $\mathrm{pH}$ differed between the SMSs in the 0-2.5 cm layer, with a higher value in the CNT than in the other systems (Table 3). In the other layers, there was a marked difference between the $\mathrm{pH}$ values of the CNT and the other management systems; however, due to the elevated CV (\%), there was no statistical difference. These higher $\mathrm{pH}$ values in the CNT system agree with the findings of Muzilli (1983) that the $\mathrm{pH}$ value in NT was equal to or higher than the value in the CT system, notably in the top 5 or $10 \mathrm{~cm}$ of the soil.

This fact can also be explained by the action of lime, which is normally restricted to the surface soil layers (Caires et al., 1998), by the greater accumulation of organic material in the soil (Sá, 1993; Sá et al., 2001) due to the less oxidative environment and reduced contact of plant residues with the soil, by the contribution of organic matter of up to $90 \%$ of the exchange capacity in the acidic soils of Paraná (Pavan et al., 1985), increasing the $\mathrm{H}^{+}$neutralization capacity, and by the hydrosoluble organic substances released in the initial period of decomposition (Franchini et al., 1999).

The increased $\mathrm{pH}$ in the CNT system may have contributed to the higher average monthly mineralization and nitrification rates in the $0-2.5 \mathrm{~cm}$ layer in this system compared to MT and CT (Table 4). According to Adams \& Martin (1984) and Silva et al. (1994), the nitrification rate decreases at $\mathrm{pH}$ under 6.0 and is insignificant at a water $\mathrm{pH}$ below 4.5 , which was not observed in this experiment. In the layers underneath, the differences in the mineralization and nitrification rates were less clear, especially between the conservation systems, which can be attributed to the lower concentration of plant residues in these layers than in the $0-2.5 \mathrm{~cm}$ layer.

In June 2004, a lower pH value was observed in all layers (Table 3). This reduction of the $\mathrm{pH}$ values can be explained by the high rainfall in May 2004 (> $200 \mathrm{~mm}$ ) (Figure 1), resulting in leaching of exchangeable bases $\left(\mathrm{K}^{+}, \mathrm{Ca}^{2+}\right.$ and $\mathrm{Mg}^{2+}$ ) and substitution by elements such as $\mathrm{H}^{+}$and $\mathrm{Al}^{3+}$. The $\mathrm{pH}$ reduction may have contributed to reduce the mineralization and nitrification rates (in the monthly averages) in the $0-2.5 \mathrm{~cm}$ soil layer of the management systems (Table 4). 
Table 4. Net $\mathrm{N}$ mineralization and nitrification rates in soil under different soil management systems in the layer 0-2.5 cm, from October 2003 to September 2004

\begin{tabular}{|c|c|c|c|c|c|}
\hline \multirow{2}{*}{ Month } & \multicolumn{5}{|c|}{ Soil management system ${ }^{(1)}$} \\
\hline & CNT & $\mathbf{N T}_{\mathbf{C H}}$ & MT & CT & Mean \\
\hline & \multicolumn{5}{|c|}{ Net mineralization rate $\left(\mathrm{kg} \mathrm{ha}^{-1}\right.$ day $\left.^{-1}\right)$} \\
\hline Oct/03 & $0.04 \mathrm{Ad}^{(2)}$ & $0.04 \mathrm{Ac}$ & $0.43 \mathrm{Aab}$ & $0.10 \mathrm{Aab}$ & $0.15 \mathrm{de}$ \\
\hline Nov/03 & 0.25 Acd & $0.30 \mathrm{Abc}$ & -0.02 Acd & $-0.03 \mathrm{Abc}$ & $0.12 \mathrm{e}$ \\
\hline Jan/04 & $0.78 \mathrm{Aab}$ & $0.43 \mathrm{ABbc}$ & $0.25 \mathrm{Babc}$ & $0.25 \mathrm{Bab}$ & $0.43 \mathrm{bc}$ \\
\hline Feb/04 & $0.56 \mathrm{Bbc}$ & $1.34 \mathrm{Aa}$ & $0.67 \mathrm{Ba}$ & $0.44 \mathrm{Ba}$ & $0.75 \mathrm{a}$ \\
\hline Mar/04 & $1.00 \mathrm{Aa}$ & $0.68 \mathrm{ABb}$ & $0.31 \mathrm{BCbc}$ & $0.14 \mathrm{Cab}$ & $0.53 \mathrm{~b}$ \\
\hline Apr/04 & $0.62 \mathrm{~A} \mathrm{abc}$ & $0.39 \mathrm{ABbc}$ & $0.13 \mathrm{Bbc}$ & $0.11 \mathrm{Bab}$ & $0.31 \mathrm{~cd}$ \\
\hline May/04 & 0.30 Acd & $0.28 \mathrm{Abc}$ & $0.12 \mathrm{Abc}$ & $0.09 \mathrm{Aab}$ & $0.20 \mathrm{de}$ \\
\hline Jun/04 & $0.22 \mathrm{Acd}$ & $0.25 \mathrm{Abc}$ & $-0.08 \mathrm{Acd}$ & $-0.04 \mathrm{Abc}$ & $0.08 \mathrm{e}$ \\
\hline $\mathrm{Jul} / 04$ & $0.59 \mathrm{Aabc}$ & $0.41 \mathrm{Abc}$ & $.0 .38 \mathrm{Bc}$ & $-0.39 \mathrm{Bc}$ & $0.05 \mathrm{e}$ \\
\hline Aug/04 & $0.10 \mathrm{Ad}$ & $0.28 \mathrm{Abc}$ & $0.16 \mathrm{Abc}$ & $0.02 \mathrm{Aabc}$ & $0.14 \mathrm{de}$ \\
\hline Mean & $0.44 \mathrm{~A}$ & $0.44 \mathrm{~A}$ & $0.16 \mathrm{~B}$ & $0.06 \mathrm{~B}$ & \\
\hline \multirow[t]{2}{*}{ CV $(\%)$} & 107.5 & & & & \\
\hline & \multicolumn{5}{|c|}{ Net nitrification rate $\left(\mathrm{kg} \mathrm{ha}^{-1}\right.$ day $\left.^{-1}\right)$} \\
\hline Oct/03 & $0.01 \mathrm{Ae}$ & $0.01 \mathrm{Ac}$ & $0.40 \mathrm{Abcd}$ & $0.19 \mathrm{Abc}$ & $0.14 \mathrm{~d}$ \\
\hline Nov/03 & 0.28 Acde & $0.32 \mathrm{Abc}$ & $0.01 \mathrm{Ad}$ & $-0.05 \mathrm{Ac}$ & $0.14 \mathrm{~d}$ \\
\hline $\mathrm{Jan} / 04$ & $1.02 \mathrm{Aab}$ & $0.86 \mathrm{Aa}$ & $0.33 \mathrm{Bbcd}$ & $0.32 \mathrm{Bbc}$ & $0.63 \mathrm{bc}$ \\
\hline Feb/04 & $0.63 \mathrm{Bbcd}$ & $1.26 \mathrm{Aa}$ & $0.65 \mathrm{Bab}$ & $0.49 \mathrm{Bb}$ & $0.76 \mathrm{ab}$ \\
\hline Mar/04 & $1.02 \mathrm{Aab}$ & $0.87 \mathrm{Aa}$ & $0.42 \mathrm{Bbc}$ & $0.31 \mathrm{Bbc}$ & $0.65 \mathrm{bc}$ \\
\hline Apr/04 & $0.66 \mathrm{Abc}$ & $0.43 \mathrm{ABb}$ & $0.13 \mathrm{Bcd}$ & $0.11 \mathrm{Bbc}$ & $0.33 \mathrm{~cd}$ \\
\hline May/04 & 0.40 Acde & $0.34 \mathrm{Abc}$ & $0.16 \mathrm{Acd}$ & $0.13 \mathrm{Abc}$ & $0.26 \mathrm{~d}$ \\
\hline Jun/0 4 & $0.26 \mathrm{Acde}$ & $0.33 \mathrm{Abc}$ & $0.02 \mathrm{Acd}$ & $-0.02 \mathrm{Ac}$ & $0.14 \mathrm{~d}$ \\
\hline $\mathrm{Jul} / 04$ & $1.25 \mathrm{Aa}$ & $1.04 \mathrm{Aa}$ & $1.03 \mathrm{Aa}$ & $0.92 \mathrm{Aa}$ & $1.06 \mathrm{a}$ \\
\hline Aug/04 & 0.23 Ade & $0.30 \mathrm{Abc}$ & $0.10 \mathrm{Acd}$ & $-0.01 \mathrm{Ac}$ & $0.15 \mathrm{~d}$ \\
\hline Sep/04 & 0.32 Acde & $0.34 \mathrm{Abc}$ & 0.12 Acd & $0.11 \mathrm{Abc}$ & $0.22 \mathrm{~d}$ \\
\hline Mean & $0.55 \mathrm{~A}$ & $0.55 \mathrm{~A}$ & $0.30 \mathrm{~B}$ & $0.22 \mathrm{~B}$ & \\
\hline CV (\%) & 71.60 & & & & \\
\hline
\end{tabular}

(1) CNT: continuous no-tillage; $\mathrm{NT}_{\mathrm{CH}}$ : no-tillage with chisel plow; MT: minimum tillage; and CT: conventional tillage. ${ }^{(2)}$ Capital letters in the rows compare soil management systems and lowercase letter in the columns compare sampling times indicate values that do not differ from each other by Student's LSD test $(\mathrm{p}<0.05)$.

\section{CONCLUSIONS}

1. The inorganic $\mathrm{N}$ transformation processes are closely related to the upper centimeters of the soil and are influenced by the presence of crop residues on the surface.

2. Lowest mineralization and nitrification rates in the systems without soil tillage occur shortly after the management of white oat.

3. Nitrogen fertilization (with urea) of wheat following soybean increases the net nitrification rates, making higher amounts of $\mathrm{N}^{-\mathrm{NO}_{3}}{ }^{-}$in the soil available.

4. Higher rainfall combined with elevated temperatures increases mineralization and nitrification rates, even in no-tillage systems in which crop residues are left on the surface.

\section{ACKNOWLEDGEMENTS}

We thank the ABC Foundation and Embrapa Agrobiology for technical support and the anonymous reviewers for their significant contributions to the manuscript.

\section{LITERATURE CITED}

ADAMS, F. \& MARTIN, J.B. Liming effects on nitrogen use and efficieny. In: HAUCK, R.D., ed. Nitrogen in crop production. Madison, American Society of Agronomy, 1984. p.417-426.

ALVAREZ, R.; ALVAREZ, C.R.; DANIEL, P.E.; RITCHTER, V. \& BLOTTA, L. Nitrogen distribution in soil density fractions and its relation to nitrogen mineralization under different tillage systems. Austr. J. Soil Res., 36:247-256, 1998.

ALVES, B.J.R.; SANTOS, J.C.F.; URQUIAGA, S. \& BODDEY, R.M. Métodos de determinação do nitrogênio em solo e planta. In: HUNGRIA, M. \& ARAUJO, R.S., eds. Manual de métodos empregados em estudos de microbiologia agrícola. Brasília, Embrapa, 1994. p.449-469.

AMADO, T.J.C.; MIELNICZUK, J.; FERNANDES, S.B.V. \& BAYER, C. Culturas de cobertura, acumulo de nitrogênio total no solo e produtividade do milho. R. Bras. Ci. Solo, 23:679-686, 1999 . 
AMADO, T.J.C.; BAYER, C.; ELTZ, F.L.F. \& BRUM, A.C.R. Potencial de culturas de cobertura em acumular carbono e nitrogênio no solo no plantio direto e a melhoria da qualidade ambiental. R. Bras. Ci. Solo, 25:189-197, 2001.

CAIRES, E.F.; CHUEIRI, W.A.; MADRUGA, E.F. \& FIGUEIREDO, A. Alterações de características químicas do solo e resposta da soja ao calcário e gesso aplicados na superfície em sistemas de cultivo sem preparo do solo. R. Bras. Ci. Solo, 22:27-34, 1998.

CAMARGO, F.A.O.; GIANELlO, C. \& VIDOR, C. Potencial de mineralização do nitrogênio em solos do Rio Grande do Sul. R. Bras. Ci. Solo, 21:575-579, 1997.

CARPENTER-BOGGS, L.; PIKUL JUNIOR, J.; VIGIL, M.F. \& RIEDELL, W.E. Soil nitrogen mineralization influenced by crop rotation and nitrogen fertilization. Soil Sci. Soc. Am. J., 64:2038-2045, 2000.

D'HAENE, K.; VANDENBRUWANE, J.; DE NEVE, S.; GABRIELS, D.; SALOMEZ, J. \& HOFMAN, G. The effect of reduced tillage on nitrogen dynamics in silt loam soils. Europ. J. Agron., 28:449-460, 2008.

DRINKWATER, L.E.; JANKE, R.R. \& LONGNECKER, L.R. Effects of tillage intensity on nitrogen dynamics and productivity in legume-based grain systems. Plant Soil, 227:99-113, 2000.

EMPRESA BRASILEIRA DE PESQUISA AGROPECUÁRIA EMBRAPA. Centro Nacional de Pesquisa de Solos. Manual de métodos de análise de solos. 2.ed. Rio de Janeiro, 1997. 212p. (Documentos, 1)

EMPRESA BRASILEIRA DE PESQUISA AGROPECUÁRIA EMBRAPA. Centro Nacional de Pesquisa de Solos. Sistema brasileiro de classificação de solos. 2.ed. Rio de Janeiro, 2006. 306p.

FRANCHINI, J.C.; MALAVOLTA, E.; MIYAZAWA, M. \& PAVAN, M.A. Alterações químicas em solos ácidos após a aplicação de resíduos vegetais. R. Bras. Ci. Solo, 23:533$542,1999$.

GREEN, C.J. \& BLACKMER, A.M. Residue decomposition effects on nitrogen availability to corn following corn or soybean. Soil Sci. Soc. Am. J., 59:1065-1070, 1995.

GROFFMAN, P.M. Nitrification and denitrification in conventional and no-tillage soils. Soil Sci. Soc. Am. J., 49:329-334, 1984.

INSTITUTO AGRONÔMICO DO PARANÁ - IAPAR. Cartas climatológicas do estado do Paraná - 1994. Londrina, 1994. 49p. (Documento, 18)

JIGGOU, W. \& BAKKEN, L.R. Competition for nitrogen during mineralization of plants residues in soil: Microbial response to C and N availability. Soil Biol. Biochem., 29:163-170, 1997.

LIEBIG, M.A.; VARVEL, G.E.; DORAN, J.W. \& WIENHOLD, B.J. Crop sequence and nitrogen fertilization effects on soil properties in the Western Corn Belt. Soil Sci. Soc. Am. J., 66:596-601, 2002.

MANSSON, K.F. \& FLKENGREN-GRERUP, U. The effect of nitrogen deposition on nitrification, carbon and nitrogen mineralization and litter C:N ratios in oak (Quercus robur L.) forests. For Ecol. Manag., 6142:1-13, 2002.
MENGEL, K. Turnover of nitrogen in soil and its availability to crops. Plant Soil, 181:83-93, 1996.

MURUGANANDAM, S.; ISRAEL, D.W. \& ROBARGE, W.P. Activities of nitrogen mineralization enzymes associated with soil aggregate size fractions of three tillage systems. Soil Sci. Soc. Am. J., 73:751-759, 2009.

MURUGANANDAM, S.; ISRAEL, D.W. \& ROBARGE, W.P. Nitrogen transformations and microbial communities in soil aggregates from three tillage systems. Soil Sci. Soc. Am. J., 74:120-129, 2010.

MUZILLI, O. Influência do sistema de plantio direto, comparado ao convencional sobre a fertilidade da camada arável do solo. R. Bras. Ci. Solo, 7:95-102, 1983.

PAVAN, M.A.; BINGHAM, F.T. \& PRATT, P.F. Chemical and mineralogical characteristics of selected acid soils of the State of Paraná, Brazil. Turrialba, 35:131-139, 1985.

PICCOLO, M.C.; NEILL, C. \& CERRI, C.C. Net mineralization and net nitrification along a tropical forest-to-pasture chronosequence. Plant Soil, 162:61-71, 1994.

PURNOMO, E.; BLACK, A.S.; SMITH, C.J. \& CONYERS, M.K. The distribution of net nitrogen mineralization within surface soil. 1.Field studies under a wheat crop. Austr. J. Soil Res., 38:129-140, 2000.

REINERTSEN, S.A.; ELLIOT, L.F.; COCHRAM, V.L. \& CAMPBELL, G.S. Role of available carbon and nitrogen in determining the rate of wheat straw decomposition. Soil Biol. Biochem., 16:459-464, 1984.

ROBERTSON, G.P. \& GROFFMAN, P.M. Nitrogen transformation. In: PAUL, E.A., ed. Soil microbiology, biochemistry, and ecology. New York, Springer, 2007. p.341-364.

ROSOLEM, C.A.; FOLONI, J.S.S. \& OLIVEIRA, R.H. Dinâmica do nitrogênio no solo em razão da calagem e adubação nitrogenada, com palha na superfície. Pesq. Agropec. Bras., 38:301-309, 2003

SÁ J.C.M. Manejo da fertilidade do solo no plantio direto. Castro, Fundação ABC, 1993. 96p.

SÁ J.C.M.; CERRI, C.C.; DICK, W.A.; LAL, R.; VENSKE FILHO, S.P.; PICCOLO, M.C. \& FEIGL, B.E. Organic matter dynamics and carbon sequestration rates for a tillage chronosequence in a Brazilian Oxisol. Soil Sci. Soc. Am. J., 65:1486-1499, 2001.

SIERRA, J. Temperature and soil moisture dependence of $\mathrm{N}$ mineralization in intact soil cores. Soil Soil Biol. Biochem., 29:1557-1563, 1997.

SILVA, C.A.; VALE, F.R. \& GUILHERME, L.R.G. Nitrificação em Latossolos da região sul de Minas Gerais: Efeito da acidez do solo. Ci. Pratica., 18:388-394, 1994.

SIQUEIRA NETO, M. Estoques de carbono e nitrogênio do solo e emissões de gases do efeito estufa no sistema plantio direto em Tibagi (PR). Piracicaba, Centro de Energia Nuclear na Agricultura, 2003 (Tese de Mestrado)

SIX, J.; ELLIOT, E.T. \& PAUSTIAN, K. Aggregate and soil organic matter dynamics under conventional and no-till systems. Soil Sci. Soc. Am. J., 63:1350-1358, 1999. 
SOUZA, W.J.O. \& MELO,W.J. Teores de nitrogênio no solo e nas frações da matéria orgânica sob diferentes sistemas de produção do milho. R. Bras. Ci. Solo, 24:885-896, 2000.

VENSKE-FILHO, S.P. Microbiota e sua atividade em uma cronossequência sob sistema plantio direto. Piracicaba, Escola Superior de Agricultura Luiz de Queiroz, 1999. 65p. (Tese de Mestrado)
WEBER, M.A. \& MIELNICZUK, J. Estoque e disponibilidade de nitrogênio no solo em experimento de longa duração. R. Bras. Ci. Solo, 33:429-437, 2009. 